\title{
Acute Kidney Injury by SARS-CoV-2 virus in patients with COVID-19: an integrative review
}

\author{
Lesão renal aguda pelo vírus SARS-COV-2 em pacientes com COVID-19: revisão integrativa \\ Lesión Renal Aguda por virus de SARS-CoV-2 en pacientes con COVID-19: revisión integrativa
}

'Universidade Federal de São Paulo. São Paulo, São Paulo, Brazil.

How to cite this article:

Moitinho MS, Belasco AGS, Barbosa DA, Fonseca CD. Acute Kidney Injury by SARS-CoV-2 virus in patients with COVID-19: an integrative review. Rev Bras Enferm. 2020;73(Suppl 2):e20200354. doi: http://dx.doi.org/10.1590/0034-7167-2020-0354

Corresponding author:

Cassiane Dezoti da Fonseca

E-mail: cassiane.dezoti@unifesp.br

EDITOR IN CHIEF: Antonio José de Almeida Filho ASSOCIATE EDITOR: Alvaro Silva

Submission: $05-04-2020$

Approval: 05-05-2020

\begin{abstract}
Objective: to assess scientific evidence on SARS-CoV-2 Acute Kidney Injury in patients with COVID-19. Methods: an integrative review, with adoption of PICO strategy and classification of the level of evidence, carried out on April 10, 2020 in the PubMed database, of articles available between December 2019 and April 2020. Results: the sample consisted of six original, five observational and one experimental articles. Observational studies addressed the clinical findings of patients with COVID-19 and association between kidney damage, infection, and morbidity-mortality. Conclusion: the studies addressed the mechanism of intracellular infection of SARS-CoV-2, its cytopathic effects on kidney cells and incidence of acute kidney injury in patients infected with SARS-CoV-2. Acute kidney injury is associated with increased mortality and morbidity in these patients. This review realizes the need for new research that can mention kidney care to patients with COVID-19.
\end{abstract}

Descriptors: Coronavirus Infections; Acute Kidney Injury; Review; Infection; Morbidity; Mortality.

\section{RESUMO}

Objetivo: avaliar as evidências científicas sobre Lesão Renal Aguda pela SARS-CoV-2 em pacientes com COVID-19. Métodos: revisão integrativa, com adoção da estratégia PICO e classificação do nível de evidência, realizada em 10 de abril de 2020 na base de dados PubMed, de artigos disponíveis entre dezembro de 2019 e abril de 2020. Resultados: a amostra foi composta por seis artigos originais, sendo cinco observacionais e um experimental. Os estudos observacionais abordaram os achados clínicos dos pacientes com COVID-19, associação entre os danos renais, infecção e morbimortalidade. Conclusão: os estudos abordaram o mecanismo de infecção intracelular da SARS-CoV-2, seus efeitos citopáticos nas células renais e a incidência de Lesão Renal Aguda nos pacientes infectados pela SARS-CoV-2. A Lesão Renal Aguda está associada ao aumento da mortalidade e morbidade nestes pacientes. Esta revisão concretiza a necessidade de novas pesquisas que possam aludir a atenção renal ao paciente com COVID-19.

Descritores: Infecções por Coronavírus; Lesão Renal Aguda; Revisão; Infecção; Morbidade; Mortalidade.

\section{RESUMEN}

Objetivo: evaluar la evidencia científica sobre la lesión renal aguda por SARS-CoV-2 en pacientes con COVID-19. Métodos: revisión integradora, con la adopción de la estrategia PICO y clasificación del nivel de evidencia, realizada el 10 de abril de 2020 en la base de datos PubMed, de artículos disponibles entre diciembre de 2019 y abril de 2020. Resultados: la muestra estuvo compuesta por seis artículos originales, cinco de los cuales son de observación y uno experimental. Los estudios de observación abordaron los hallazgos clínicos de pacientes con COVID-19, la asociación entre daño renal, la infección y la morbilidad y mortalidad. Conclusión: los estudios abordaron el mecanismo de infección intracelular del SARS-CoV-2, sus efectos citopáticos en las células renales y la incidencia de lesión renal aguda en pacientes infectados con el SARS-CoV-2. La Lesión Renal Aguda se asocia con una mayor mortalidad y morbilidad en estos pacientes. Esta revisión resalta la necesidad de más investigación que pueda aludir la atención renal a pacientes con COVID-19.

Descriptores: Infecciones por Coronavirus; Lesión Renal Aguda; Revisión; Infección; Morbilidad; Mortalidad. 


\section{INTRODUCTION}

Coronavirus makes up a family of viral pathogens that co-infect humans and other vertebrates ${ }^{(1-2)}$. Among its variants, two of them are old known for inducing numerous emergency outbreaks of Severe Acute Respiratory Syndrome (SARS) and Middle East Respiratory Syndrome (MERS) in 2003 and 2012, respectively ${ }^{(2-3)}$. Recently, especially in December 2019, a series of unspecified pneumonias were reported in the city of Wuhan-China, a place known for existence of newly sacrificed animal markets. Some Chinese studies have warned since 2007, classifying this type of trade as highly probable for future outbreaks of coronaviruses similar to SARS or MERS ${ }^{(4-5)}$. Possible novel epidemics stood out, with China as the likely focus of the epidemic, highlighting these trades as a source and amplification centers for emerging infections ${ }^{(4-5)}$.

The novel coronavirus was named SARS-CoV-2 (Severe Acute Respiratory Syndrome Coronavirus 2), and on February 11, 2020, WHO officially called COVID-19 the disease caused by the virus ${ }^{(4-5)}$. On March 11, 2020, COVID-19 soon surpassed continental barriers and became a declared pandemic, characterized by its high transmissibility, mainly by droplets and aerosols. There was evidence of community transmission in dozens of countries, issuing a global and universal health safety alert ${ }^{(6-7)}$.

COVID-19 is identified as the cause of exponential SARS outbreaks around the world. Its common clinical manifestation varies from asymptomatic forms to symptomatic clinical conditions, usually including fever, cough, myalgia, and/or fatigue. Dyspnea is considered a worrying and incident symptom in more than half of the cases ${ }^{(7-8)}$, in addition to less common symptoms such as sputum production, headache, hemoptysis, diarrhea, among others $^{(8-9)}$. Some evidence points to about 5 days as the average incubation period for SARS-CoV-2; from the onset of symptoms to the need for hospitalization, about 7 days; and progression to dyspnea, around 8 days ${ }^{(9)}$.

SARS, MERS, and COVID-19 generate inflammatory aspects, with release and increase of pro-inflammatory cytokines, leading to infiltration of inflammatory cells in the pulmonary system, interstitial edema and injury and destruction of the lung parenchyma ${ }^{(8-11)}$. Histologically, diffuse alveolar damage is closely linked to the acute phase of infection ${ }^{(12)}$. The pathogenic mechanism that induces pulmonary involvement appears to be particularly complex and not yet fully understood ${ }^{(7,12)}$.

In addition to the widespread and diffuse pulmonary involvement, some studies have identified that in severe cases of COVID-19 an exacerbated immune response occurs, haemophagocytic lymphohistiocytosis or also known as a 'cytokine storm'. As a result, there is loss of peripheral tolerance to the organs themselves, which become antigenic, triggering rapid progression to SARS, extensive inflammation and tissue self-destruction in several organs $s^{(11,13-14)}$.

Interleukin 6 (IL-6), capable of promoting differentiation of B lymphocytes, growth and inhibition of some categories of cells, stimulates the production of pro-inflammatory proteins $s^{(7,14-15)}$. According to recent studies, increased IL-6, d-dimer and serum ferritin levels obtained a statistical association with the death of some patients, being one of possible targets for future treatment of severe cases of COVID-19 pneumonia ${ }^{(7,14-17)}$.
In addition to pulmonary and immunological impairments resulting from infection by SARS-CoV-2, some studies have sought to relate it to injuries to other organs and systems. In this context, the renal system has gained focus and relevance in scientific studies. Although evidence is still scarce, some Chinese studies, even with low incidence, suggested occurrence of kidney damage in patients with COVID-19 ${ }^{(18-20)}$. Furthermore, such studies suggest that increase in some renal function parameters such as proteinuria, hematuria, urea, and serum creatinine $(\mathrm{SCr})$ were significantly associated with a statistically significant risk of mortality of up to five times greater in this group ${ }^{(18-19)}$.

Although some articles suggest a possible mechanism of Acute Kidney Injury (AKI) by COVID-19, other studies claim that there is no AKI resulting from this infection, claiming that the extrapulmonary damage by SARS-CoV-2 was not detected in other organs ${ }^{(12,21)}$. On the other hand, other scientific evidence suggests that this infection is not limited to the lung parenchyma, with evidence of virus particles in kidney cells ${ }^{(1,18-19)}$.

Considering this divergent scenario and taking into account the problem magnitude and scarcity of studies on this emerging theme, we are motivated to carry out this review to verify, through current scientific evidence on AKI in patients with COVID-19, possible deleterious renal effects induced by SARS-CoV-2.

\section{OBJECTIVE}

To show and assess available scientific evidence on possible AKI mechanism by SARS-CoV-2 in patients with COVID-19.

\section{METHOD}

This integrative review ${ }^{(22-23)}$ searched for scientific productions in the PubMed database of articles published between December 2019 and April 2020, with the adoption of descriptors (Mesh) "Acute Kidney Injury" AND "COVID-19".

PICO strategy was used as a way to guide the search for scientific studies and to find the best scientific evidence for an integrative review. This strategy symbolizes an acronym for Patient or Problem, Intervention, Comparison or Control and Outcome ${ }^{(24)}$. The search strategy took place in four steps: (1) identification of a clinical problem; (2) formulation of a relevant and specific clinical question; (3) search for scientific evidence and (4) assessment of available evidence. Therefore, we followed classification and analysis of the four parameters aimed at identifying the problem. The first criterion (Patient) was identification of the group to be studied, i.e., patients with COVID-19 and their renal parameters; the second (Intervention), analysis of availability and assessment of scientific evidence; the third (Comparison), this study did not cover a comparison group; the fourth (Outcomes), analysis of epidemiological, laboratory, experimental aspects, among others, on patients' renal function.

The guiding question to create the integrative review was: what is the current scientific evidence regarding renal function impairment by SARS-CoV-2 in patients with COVID-19? The articles found were analyzed according to the selection order. Data were analyzed, according to their content, through investigation of two researchers. The search criteria are described in Table 1 and Figure 1. 
Table 1 - Search results in the databases to analyze the records found in articles, São Paulo, São Paulo, Brazil, 2020

\begin{tabular}{cc}
\hline Search strategy & “Acute Kidney Injury" AND “COVID-19” \\
\hline PubMults: 13 \\
Full text: 13 \\
\\
Filter application of the last 5 months: 13 \\
Selected: 8 \\
\hline
\end{tabular}

Original published studies on the proposed topic, in Spanish, Portuguese and English, available in full for reading and that addressed as a main subject renal function assessment in patients infected with and/or with COVID-19 were included. Other reviews and studies that did not mention SARS-CoV-2 and/or COVID-19 were excluded from the sample. Following the search criteria, a flow diagram (according to PRISMA) was created in the database search (Figure 1).

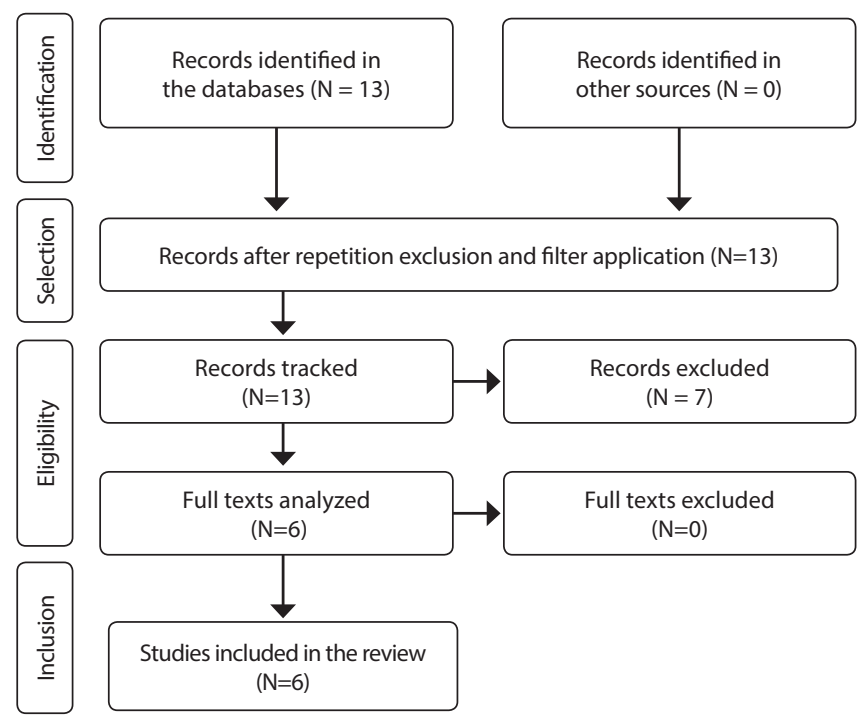

Figure 1 - Flowchart of the steps regarding search for evidence in the databases, according to PRISMA, São Paulo, São Paulo, Brazil, 2020
The articles found were classified according to the type of research and level of evidence: Level 1 - evidence from systematic review or meta-analysis; Level 2 - evidence derived from at least one well-outlined randomized controlled clinical trial; Level 3 - evidence obtained from well-outlined clinical trials without randomization; Level 4 - evidence from well-outlined cohort and case control studies; Level 5 - evidence from systematic review of descriptive and qualitative studies; Level 6 - evidence derived from a single descriptive or qualitative study; Level 7 - evidence from the opinion of authorities and/or expert committee report ${ }^{(25)}$.

\section{RESULTS}

Thirteen articles were found in the database described, then they were selected to full reading of their respective abstracts. Nine articles were selected whose content included the research question. After reading the abstracts, the four articles were excluded because: (1) the studies were not original or did not have an outline with data that could be properly analyzed for review $(n=4) ;(2)$ the articles did not discuss or address in any way the effects of SARS-CoV-2 viral infection on patients' renal function ( $\mathrm{n}$ $=2)$; (3) the article was a review $(n=1)$. At the end of an analytical full reading and after exclusions, the sample consisted of six articles that met all the inclusion criteria.

The studies were published between February 24, 2020 and April 3, 2020. The works found were from China, five from the city of Wuhan ${ }^{(19,21,26-28)}$ and one from Shanghai( ${ }^{(20)}$, being analyzed in English. The studies were published in different medical journals $(100 \%)^{(19-21,26-28)}$. Concerning research design, it was observed that the five studies were original, being five observational and one experimental. Among these studies, 2 were case-control (33.3\%), 2 were cohort (33.3\%), and 2 were descriptive (33.3\%). Data is present chronologically in Table 2 , according to the most recent evidence.

Chart 1 - Distribution of studies according to title, authors, place, year, and journal, São Paulo, São Paulo, Brazil, 2020

\begin{tabular}{|c|c|c|c|c|c|}
\hline $\mathbf{N}$ & Title & Authors & Year & Place & Journal \\
\hline (1) & $\begin{array}{l}\text { Identification of a potential mechanism of acute } \\
\text { kidney injury during the COVID-19 outbreak: } \\
\text { a study based on single-cell transcriptome } \\
\text { analysis }{ }^{(20)} \text {. }\end{array}$ & $\begin{array}{l}\text { Pan XW, Xu D, Zhang H, Zhou W, Wang LH, Cui } \\
\text { XG. }\end{array}$ & $\begin{array}{l}\text { March 31, } \\
2020\end{array}$ & $\begin{array}{l}\text { Shanghai- } \\
\text { China }\end{array}$ & $\begin{array}{l}\text { Intensive } \\
\text { Care } \\
\text { Medicine }\end{array}$ \\
\hline (2) & $\begin{array}{l}\text { Coronavirus Disease } 19 \text { Infection Does Not } \\
\text { Result in Acute Kidney Injury: An Analysis of } 116 \\
\text { Hospitalized Patients from Wuhan, China }{ }^{(21)} \text {. }\end{array}$ & Wang L, Li X, Chen H, Yan S, Li D, Li Y, Gong Z. & $\begin{array}{l}\text { March 31, } \\
2020\end{array}$ & $\begin{array}{l}\text { Wuhan- } \\
\text { China }\end{array}$ & $\begin{array}{l}\text { American } \\
\text { Journal of } \\
\text { Nephrology }\end{array}$ \\
\hline (3) & $\begin{array}{l}\text { Clinical characteristics of } 113 \text { deceased patients } \\
\text { with coronavirus disease 2019: retrospective } \\
\text { study }{ }^{(26)} \text {. }\end{array}$ & $\begin{array}{l}\text { Chen T, Wu D, Chen H, Yan W, Yang D, Chen G, } \\
\text { Ma K, Xu D, Yu H, Wang H, Wang T, Guo W, Chen } \\
\text { J, Ding C, Zhang X, Huang J, Han M, Li S, Luo X, } \\
\text { Zhao J, Ning Q. }\end{array}$ & $\begin{array}{l}\text { March 26, } \\
2020\end{array}$ & $\begin{array}{l}\text { Wuhan- } \\
\text { China }\end{array}$ & The BMJ \\
\hline (4) & $\begin{array}{l}\text { Clinical characteristics of fatal and recovered } \\
\text { cases of coronavirus disease } 2019 \text { (COVID-19) in } \\
\text { Wuhan, China: a retrospective study }{ }^{(27)} \text {. }\end{array}$ & $\begin{array}{l}\text { Deng Y, Liu W, Liu K, Fang YY, Shang J, Zhou L, } \\
\text { Wang K, Leng F, Wei S, Chen L, Liu HG. }\end{array}$ & $\begin{array}{l}\text { March 20, } \\
2020\end{array}$ & $\begin{array}{l}\text { Wuhan- } \\
\text { China }\end{array}$ & $\begin{array}{l}\text { Chinese } \\
\text { Medical } \\
\text { Journal }\end{array}$ \\
\hline (5) & $\begin{array}{l}\text { Kidney disease is associated with in-hospital } \\
\text { death of patients with COVID- } 19^{(19)} \text {. }\end{array}$ & $\begin{array}{l}\text { Cheng Y, Luo R, Wang K, Zhang M, Wang Z, Dong } \\
\text { L, Li J, Yao Y, Ge S, Xu G. }\end{array}$ & $\begin{array}{l}\text { March 20, } \\
2020\end{array}$ & $\begin{array}{l}\text { Wuhan- } \\
\text { China }\end{array}$ & $\begin{array}{l}\text { Kidney } \\
\text { International }\end{array}$ \\
\hline (6) & $\begin{array}{l}\text { Clinical course and outcomes of critically } \\
\text { ill patients with SARS-CoV-2 pneumonia in } \\
\text { Wuhan, China: a single-centered, retrospective, } \\
\text { observational study }{ }^{(28)} \text {. }\end{array}$ & $\begin{array}{l}\text { Yang X, Yu Y, Xu J, Shu H, Xia J, Liu H, Wu Y, Zhang } \\
\text { L, Yu Z, Fang M, Yu T, Wang Y, Pan S, Zou X, Yuan } \\
\text { S, Shang Y }\end{array}$ & $\begin{array}{l}\text { February } \\
24 \\
2020\end{array}$ & $\begin{array}{l}\text { Wuhan- } \\
\text { China }\end{array}$ & $\begin{array}{l}\text { The Lancet } \\
\text { Respiratory } \\
\text { Medicine }\end{array}$ \\
\hline
\end{tabular}


Chart 2 - Synoptic table containing the research design, objective, main results and conclusion, of the articles selected for integrative review, São Paulo, São Paulo, Brazil, 2020

\begin{tabular}{|c|c|c|c|}
\hline $\begin{array}{l}\text { Outlining/Level } \\
\text { of Evidence/ } \\
\text { number of } \\
\text { patients }\end{array}$ & Objective & Main results & Conclusion \\
\hline $\begin{array}{l}\text { (1) Experimental, } \\
\text { descriptive study/ } \\
\text { Level } 5 / \mathrm{n}=\text { not } \\
\text { applicable }^{(20)} \text {. }\end{array}$ & 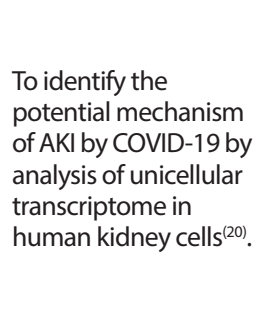 & $\begin{array}{l}\text { The location of the genes angiotensin-converting enzyme } 2 \text { (ACE2) and } \\
\text { transmembrane serine proteases (TMPRSS) showed relatively high co- } \\
\text { expression in podocytes and proximal straight tubule cells. Candidate host } \\
\text { cells for SARS-CoV-2 have been showed. TMPRSS2 enters host cells and is } \\
\text { co-expressed with ACE2 in podocytes. There was no significant difference in } \\
\text { the expression of TMPRSS and the ACE2 receptor in podocytes and cells in } \\
\text { proximal straight tubules. Comparative analysis showed that co-expression } \\
\text { of genes in renal cells was not inferior to that of the lung, esophagus, small } \\
\text { intestine and colon, suggesting that the kidney may be an important target } \\
\text { for this virus }{ }^{(20)} \text {. }\end{array}$ & $\begin{array}{l}\text { Viral (SARS-CoV-2) cytopathic } \\
\text { effect on podocytes and } \\
\text { proximal straight tubules } \\
\text { can cause AKI. The proposed } \\
\text { mechanism for the } \\
\text { pathophysiology of AKI during } \\
\text { COVID-19 has yet to be validated } \\
\text { in autopsies and in experiments } \\
\text { on animals and cells }{ }^{(20)} \text {. }\end{array}$ \\
\hline $\begin{array}{l}\text { (2) Descriptive } \\
\text { study/ Level 5/ } \\
n=116^{(21)} \text {. }\end{array}$ & $\begin{array}{l}\text { To explore the effects } \\
\text { of SARS-CoV-2 } \\
\text { infection on renal } \\
\text { function by analyzing } \\
\text { the clinical data of } \\
116 \text { hospitalized } \\
\text { COVID-19 confirmed } \\
\text { patients }^{(21)} \text {. }\end{array}$ & $\begin{array}{l}\text { Twelve (10.8\%) showed a slight increase in blood urea nitrogen or SCr. Eight } \\
(7.2 \%) \text { patients had a trace or } 1+\text { albuminuria in patients without chronic } \\
\text { kidney disease (CKD). All of these patients did not meet the AKI diagnostic } \\
\text { criteria. During treatment, renal function indicators showed stable status } \\
\text { in patients with CKD, without exacerbation of CKD, and pulmonary } \\
\text { inflammation was gradually absorbed. SARS-CoV- } 2 \text { RNA in the urine } \\
\text { sediment was positive only in } 4 \text { patients out of } 53 \text { cases and } 1 \text { patient had a } \\
\text { positive result in the SARS-CoV-2 open reading frame }{ }^{(21)} \text {. }\end{array}$ & $\begin{array}{l}\text { AKI was unusual in COVID-19. } \\
\text { SARS-CoV-2 infection does not } \\
\text { result in AKI or worsens CKD in } \\
\text { patients with COVID-19(21). }\end{array}$ \\
\hline $\begin{array}{l}\text { (3) Retrospective } \\
\text { cohort study/ } \\
\text { Level } 4 / n=113^{(26)} \text {. }\end{array}$ & $\begin{array}{l}\text { To outline the clinical } \\
\text { characteristics } \\
\text { of patients with } \\
\text { COVID-19 who } \\
\text { died }^{(26)} \text {. }\end{array}$ & $\begin{array}{l}\text { Deceased patients, compared to recovered ones, were older ( } 68 \text { and } \\
51 \text { years old, respectively), male, with chronic hypertension and other } \\
\text { cardiovascular comorbidities (54 [48\%] and } 16[14 \%]) \text {. They had dyspnea, } \\
\text { chest tightness and consciousness disorder }(70[62 \%], 55[49 \%] \text { and } 25 \\
\text { [22\%]). Leukocytosis was present in } 56(50 \%) \text { of deceased patients and } \\
\text { in } 6(4 \%) \text { of those who recovered, and lymphopenia was present in } 103 \\
(91 \%) \text { and } 76(47 \%) \text { patients. Alanine aminotransferase (ALT), aspartate } \\
\text { aminotransferase (AST), creatinine, creatine kinase, lactate dehydrogenase, } \\
\text { cardiac troponin I, N-terminal pro-brain natriuretic peptide and D-dimer } \\
\text { levels were higher. The most common complications were acute respiratory } \\
\text { distress syndrome (ARDS) (113; [100\%]), type I respiratory failure (18/35; } \\
[51 \%]) \text {, sepsis (113 [100\%]), acute cardiac injury (72/94; [77\%]), alkalosis } \\
(14 / 35[40 \%]) \text { and AKI }(28[25 \%])^{(26)} \text {. }\end{array}$ & $\begin{array}{l}\text { SARS-CoV-2 infection can } \\
\text { cause pulmonary and systemic } \\
\text { inflammation, leading to } \\
\text { multiple organ dysfunction in } \\
\text { high-risk patients. ARDS and } \\
\text { respiratory failure, sepsis, acute } \\
\text { cardiac injury and heart failure } \\
\text { were the most common critical } \\
\text { complications of COVID-19(26). }\end{array}$ \\
\hline $\begin{array}{l}\text { (4) Retrospective } \\
\text { control group } \\
\text { study/Level 4/ } \\
\mathrm{n}=964^{(27)} \text {. }\end{array}$ & $\begin{array}{l}\text { To investigate the } \\
\text { characteristics } \\
\text { of dead patients } \\
\text { and provide some } \\
\text { ideas on COVID-19 } \\
\text { treatment }{ }^{(27)} \text {. }\end{array}$ & $\begin{array}{l}\text { The mean age was higher in the deceased group compared to recovered }(P \\
<0.001) \text {, underlying diseases }(P<0.001) \text {, longer time from disease onset to } \\
\text { hospitalization }(Z=3.216, P=0.001) \text {. Upon admission, there was a greater } \\
\text { proportion of dyspnea }(X=60.905, P /<0.001) \text { and sputum }(X=13.250, P \\
<0.001) \text {. The deceased group exhibited a lymphocyte count }(Z=8.037, P \\
<0.00 \text { a } 1) \text { and a lymphocyte/leukocyte proportion }(Z=10.315, P<0.001) \\
\text { that was lower at admission and hospitalization }(Z=5.242, P<0.001) \text {. ALT }(Z \\
=2.592, P=0.010), A S T(Z=7.308, P<0.001) \text { and creatinine levels }(Z=6.478 \text {, } \\
P<0.001) \text { were higher in the deceased group. } C \text {-reactive protein }(C R P) \text { were } \\
\text { also higher }(Z=10.206, P<0.001) \text {. The deceased group had more ARDS }(X \\
=148.105, P<0.001) \text {, acute cardiac injury }(X=93.222, P<0.001), A K I(X= \\
23.257, P<0.001) \text {, and shock }(X=14.618, P<0.001)^{(27)} \text {. }\end{array}$ & $\begin{array}{l}\text { Compared to the recovered } \\
\text { group, more patients in the } \\
\text { deceased group exhibited } \\
\text { characteristics of advanced } \\
\text { age, pre-existing comorbidities, } \\
\text { dyspnea, low oxygen saturation, } \\
\text { increased leukocytes, decreased } \\
\text { lymphocytes and elevated } \\
\text { CRP levels. In addition, they } \\
\text { presented ARDS, acute cardiac } \\
\text { injury, AKI, shock, and IHD }\end{array}$ \\
\hline $\begin{array}{l}\text { (5) - Prospective } \\
\text { cohort study, } \\
\text { Level } 4 / n=701^{(19)} \text {. }\end{array}$ & $\begin{array}{l}\text { To assess the } \\
\text { association between } \\
\text { abnormal renal } \\
\text { function markers and } \\
\text { death in patients with } \\
\text { COVID-19 } 9^{(19)} \text {. }\end{array}$ & $\begin{array}{l}\text { Upon admission, } 43.9 \% \text { of the } 701 \text { patients had proteinuria and } 26.7 \% \text { had } \\
\text { hematuria. High SCr prevalence was } 14.4 \% \text {, high blood urea nitrogen was } \\
13.1 \% \text { and low glomerular filtration rate was } 13.1 \% \text {. AKI occurred in } 5.1 \% \text { of } \\
\text { patients. High basal SCr (risk rate: } 2.10,1.36-3.26) \text {, high basal urea nitrogen } \\
(3.97,2.57-6.14) \text {, AKI stage } 1(1.90,0,76-4.76) \text {, stage } 2(3.51,1.49-8.26) \text {, stage } \\
3(4.38,2.31-8.31) \text {, proteinuria } 1+(1.80,0,81-4.00), 2+\sim 3+(4.84,2.00- \\
11.70) \text { and hematuria } 1+(2.99,1.39-6.42), 2+\sim 3+(5.56,2.58-12.01) \text { were } \\
\text { independent risk factors for death }{ }^{(19)} \text {. }\end{array}$ & $\begin{array}{l}\text { Prevalence of kidney } \\
\text { disease upon admission and } \\
\text { development of AKI during } \\
\text { hospitalization in patients } \\
\text { with COVID-19 was high and } \\
\text { is associated with hospital } \\
\text { mortality }{ }^{(19)} \text {. }\end{array}$ \\
\hline $\begin{array}{l}\text { (6) Retrospective } \\
\text { epidemiological } \\
\text { study, Level 4/ } \\
\mathrm{n}=52^{(28)} \text {. }\end{array}$ & $\begin{array}{l}\text { To describe the } \\
\text { clinical course and } \\
\text { outcomes of critically } \\
\text { ill patients with SARS- } \\
\text { CoV-2 pneumonia }{ }^{(28)} \text {. }\end{array}$ & $\begin{array}{l}\text { The mean age of the } 52 \text { patients was } 59.7 \text { years old (SD 13.3), the majority } \\
35(67 \%) \text { were men, } 21(40 \%) \text { had chronic diseases and } 51 \text { (98\%) had fever. } \\
\text { Thirty-two (61.5\%) patients died after } 28 \text { days of hospitalization and the } \\
\text { median duration of admission to the intensive care unit (ICU) until death } \\
\text { was } 7 \text { days (IQR 3-11). Compared to survivors, non-survivors were older } \\
\text { (64.6 years old [11.2] vs } 51.9 \text { years old [12.9]). Twenty-six (81\%) patients } \\
\text { vs nine (45\%) patients were more likely to develop ARDS and to receive } \\
\text { mechanical ventilation (30 [94\%] vs } 7 \text { [35\%]). From clinical evolution, (35 } \\
\text { [67\%]) with ARDS, (15 [29\%]) with AKI and (12 [23\%]) with cardiac injury }{ }^{28)} \text {. }\end{array}$ & $\begin{array}{l}\text { The survival time of non- } \\
\text { survivors is likely to be } 1 \text { to } 2 \\
\text { weeks after admission to the } \\
\text { ICU. Elderly patients (> } 65 \text { years) } \\
\text { with comorbidities and ARDS } \\
\text { are at increased risk of death }{ }^{(28)} \text {. }\end{array}$ \\
\hline
\end{tabular}


Of the six selected articles, all made reference to AKI, SARSCoV-2 and COVID-19. The studies covered levels 4 and 5 of evidence, with levels 4 predominating (66.6\%). The results are synthesized in Chart 2.

\section{DISCUSSION}

The mechanism of intracellular infection of SARS-CoV-2, despite not being fully elucidated, underscores the need for incessant research. Some studies indicate that ACE2 is one of the main receptors that mediate pathogen entry into human cells $s^{(20,29)}$. As in the infection caused by SARS-CoV, a protein, called Spike (S), present in SARS-CoV-2, binds to ACE2 on host cell surface, allowing protein $S$ to be activated and cleaved by TMPRSS. This causes the virus to release some fusion peptides to attach to the cell membrane, a central mechanism in determining tissue tropism, and thus entering the cell(20,29-30).

In the lungs, human alveolar epithelial cells appear to be a more vulnerable target for infection ${ }^{(20,29-31)}$. This can be explained by the vast area of the lung surface that increases susceptibility to the inhaled virus, as well as by the majority of cells that express ACE2 being type II alveolar epithelial cells, which serve as a reservoir for viral invasion, in addition to other genetic factors ${ }^{(30-31)}$. However, ACE2 expression is also found in many extrapulmonary tissues ${ }^{(20,29-31)}$.

Therefore, as reported by Pan et al. ${ }^{(20)}$, ACE2 and TMPRSS coexpression is an essential determinant for SARS-CoV-2 entry into host cells. In their study, despite the research design being enunciated with a low level of evidence and having adequate scientific rigor, they were experimentally based on an analysis of normal kidney cells at the single cell level, showing high co-expression of ACE2 and TMPRSS in podocytes and cells of the proximal straight tubule ${ }^{(20)}$. Other studies also indicate that ACE2 is also highly expressed in Leydig cells and seminiferous duct cells in the testicle ${ }^{(20,29-30)}$.

Thus, Pan et al. ${ }^{(20)}$ state that viral cytopathic effect on renal cells can cause AKI and damage the kidney and its function in patients with SARS-CoV-2(20). However, clinical-observational evidence from cohort and epidemiological studies point out AKI, kidney damage and dysfunction caused by SARS-CoV-2 as a still controversial and debatable topic ${ }^{(20-21)}$.

In the publications reached in this review, the number (n) of populations composed of patients infected with SARS-CoV-2 and hospitalized with COVID-19 ${ }^{(20-21)}$, whether the samples of groups that died ${ }^{(26-27)}$ or of patients who were in the most severe state

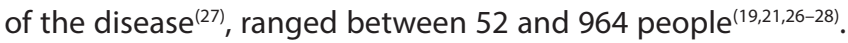
Concerning clinical and sociodemographic profile of samples, in general, the patients were mostly men ranging from $52.4 \%$ to $73 \%$, with a mean age of 54 to 69 years ${ }^{(19,21,26-28)}$. They had at least $40 \%$ to $48 \%$ clinical comorbidity ${ }^{(19,28)}$. Systemic hypertension was present in $33.4 \%$ to $37.1 \%$ of the total number of patients, with a prevalence of $36.7 \%$ to $48 \%$ in the groups of the deceased who raised the basal $\mathrm{SCr}$ during the disease, or those who attended with a severe level of COVID-19 ${ }^{(19,21,26-28)}$. Diabetes Mellitus showed a prevalence between $14.3 \%$ and $15.5 \%$, rising to up to $16 \%$ when analyzed only in individuals who had increased $\mathrm{SCr}^{(19,21)}$.

According to the reviewed studies, some type of mechanical ventilation was required in $13.4 \%(97 / 701)^{(19)}$ of all patients with COVID-19 and 71\% (37/52) of the most critical patients. Among these more severe patients, mechanical ventilation was $94 \%$ in those who died and $35 \%$ in those who survived ${ }^{(28)}$. The mean time from illness until hospitalization was 7 days for the group of survivors of COVID-19 and 10 days for the deceased ${ }^{(27)}$. The median duration between the onset of symptoms until admission was 10 days, 9 days for those who had increased $\mathrm{SCr}$ during hospitalization ${ }^{(19)}$ and 9 days for critically ill patients from the onset of symptoms to transfer to ICU ${ }^{(28)}$. ICU admission was $9.5 \%(11 / 116)^{(21)}$ and $10.4 \%(73 / 701)$, among the latter ICU admission of those who had increased $\mathrm{SCr}$ was $12.8 \%(13 / 101)^{(19)}$. The aforementioned can show that patients with worse prognosis were already admitted with worse conditions and had a rapid evolution of the disease.

The most common signs and symptoms manifested by the studied patients were fever, affecting up to $98 \%$ (51/52) in critically ill patients ${ }^{(28)}$; sputum, up to $32.1 \%(35 / 109)$ in hospitalized patients who had an outcome of death, $15.7 \%(n=116)$ in those who survived ${ }^{(26)}$ and $77 \%$ (40/52) in critically ill patients ${ }^{(28)}$; dyspnea, up to $62 \%(70 / 113)^{(26)}$ and $70.6 \%(77 / 109)^{(27)}$ in patients who died, $31 \%(50 / 161)^{(26)}$ and $24.7 \%(22 / 116)^{(27)}$ in those who survived and up to $63 \%$ (33/52) in most critical patients ${ }^{(26)}$. These symptoms have already been inferred by the world authorities as highly related to the disease ${ }^{(32-33)}$.

In these observational studies, data on the incidence of AKI in patients admitted for COVID-19 can be pointed out as inconsistent, ranging from $0 \%(0 / 116)$, as portrayed by Wang et al. ${ }^{(21)}$ to $29 \%(15 / 52)$, as described by Yang et al. ${ }^{(28)}$, in critically ill patients.

Furthermore, Cheng et al. ${ }^{(19)}$, in their study on the association of renal dysfunction and COVID-19, reveals that even though the incidence of AKI in their study was 5.1\%, high SCr prevalence, blood urea nitrogen and low glomerular filtration (less than 60 $\mathrm{ml} / \mathrm{min} / 1.73 \mathrm{~m} 2$ ) were $14.4 \%, 13.1 \%$ and $13.1 \%$. There were 101 patients with increased SCr in 701 cases of COVID-19 ${ }^{(19)}$. However, although $\mathrm{SCr}$ was elevated, a good part was within the normal range and/or not all met the defined prerequisites for the diagnosis of AKI. The standard definition of AKI used in adults in the studies was based on the Clinical Practice Guideline for Acute Kidney Injury (KDIGO), which considers an increase in $\mathrm{SCr} \geq 26 \mu \mathrm{mol} / \mathrm{L}(0.3$ $\mathrm{mg} / \mathrm{dL}$ ) within 48 hours, or increase in $\mathrm{SCr}>1.5$ times, in the base value, considering the previous 7 days, or urine volume $<0.5 \mathrm{~mL} /$ $\mathrm{kg} / \mathrm{h}$ for more than 6 hours ${ }^{(34)}$.

Likewise, other renal parameters were assessed in these and other studies, in order to ascertain other renal indicators to track possible renal impairment in patients with COVID-19. Some studies have shown that proteinuria was a common finding in those infected by the virus, data by Chen et al..$^{(26)}$ showed it with a high incidence, 60\% (100/166) in all patients, $86 \%(42 / 49)$ in those who died and 50\% (58/117) among those who were cured ${ }^{(26)}$. Hematuria was also screened in some studies of this review, highlighting the findings by Chen et al. ${ }^{(26)}$, which showed the presence of $83 \%$ (40/49) of this clinical sign in the deceased group ${ }^{(26)}$. Much scientific evidence confirms common prevalence of proteinuria and hematuria in patients with COVID-19 ${ }^{(18-19,21,26,35)}$. Pan et al. ${ }^{(20)}$ state that podocytes are particularly vulnerable to viral and bacterial attacks, and podocyte damage easily induces intense proteinuria ${ }^{(20,36)}$.

It should be noted that the study by Deng et al. ${ }^{(27)}$ has AKI as one of the significantly more common complications in patients who died of COVID-19 ${ }^{(27)}$. Cheng et al. ${ }^{(19)}$ classifies basal SCr elevation with a risk rate for death at 2.10 (1.36-3.26), an elevated basal 
urea nitrogen at 3.97 (2.57-6.14), stage $3 \mathrm{AKI}$ at 4.38 (2.31-8.31), proteinuria above level two at 4.84 (2.00 - 11.70) and hematuria above level at 5.56 (2.58-12.01), characterizing them as independent risk factors for hospital death ${ }^{(27)}$. They compact with studies that already expose renal dysfunctions as predictors of death by COVID-19 in up to five times more chances of death ${ }^{(17,26-27,33)}$.

The possible mechanism of renal dysfunction or AKI in patients with COVID-19 is still unclear, as already discussed. However, it is speculated that it is related to three main mechanisms, despite the need for further studies for their respective confirmations.

The first mechanism refers to direct attack of the virus, as already explained, SARS-CoV-2 often enters cells through connection to $A C E 2^{(20,29,31,37)}$. Relative high expression of this receptor has already been shown in renal cells, suggesting that these cells

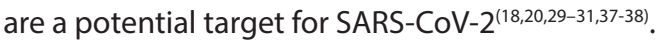

In addition to direct attack to the kidney, evidence has shown a tendency to immunomediated injury as a cause of AKI and renal dysfunction, which is the second possible mechanism ${ }^{(11,13-14)}$. By this means, pro-inflammatory mediators are produced at excessive levels, which can commonly lead to pulmonary inflammation and respiratory failure ${ }^{(11)}$. Moreover, their potential systemic effect may be involved in the occurrence and development of AKI and multiple organ dysfunction ${ }^{(11-14,20,28)}$. In studies on SARS-CoV-2, most cells expressing ACE2 proteins and SARS-CoV-2 were reactive against Transforming Growth Factor Beta (TGF $\beta 1$ ), Tumor Necrosis Factors Alpha (TNF a), IL $1 \beta$ and IL $6^{(39)}$, suggesting overproduction in infected patients ${ }^{(11,39-42)}$.

Furthermore, in a retrospective multicenter cohort study, a significant increase in the level of IL- 6 was reported in the group with no survival of patients with COVID-19, compared to that of survival(15). Thus, the unregulated or exacerbated immune response can significantly induce damage to other tissues, thus proposing an important COVID-19 mechanism ${ }^{(11,39-44)}$.

One of the well-known findings in four of the five observational studies analyzed in this review was the detection of increased leukocytes and decreased lymphocytes in blood samples ${ }^{(19,26-28)}$. Some studies show that the counts of some immune cells are substantially reduced, but their status may be hyperactivated ${ }^{(11,35)}$. As discussed by Chen et al.(26) and Deng et al. (27), this immunological overactivation can manifest high cytotoxicity in this class of cells and be responsible to some extent for severe multiorgan immune damage $\mathrm{e}^{(11,26-27,35,41,43)}$.

Finally, the third and last possible mechanism for renal tissue damage by COVID-19 may be associated secondarily to patients with COVID-19 in serious condition, through the susceptibility of this group to sepsis and septic shock, which may increase occurrence or worsening AKI related to sepsis due to excessive inflammation, apoptosis, and mitochondrial stress ${ }^{(45-46)}$. Moreover, they can easily develop hypovolemia, increasing kidney hypoperfusion and AKI. Hospital therapy, which can also probably cause AKI related to pharmacotherapy, is also noteworthy ${ }^{(45)}$.

\section{Study limitations}

The main limitation found in this review was the scarcity of articles that answered the guiding question of the study. It was considered reasonable in considering the uniqueness and originality of the current situation and the limited time for conducting research on the subject.

\section{Contributions to nursing, health, and public policies}

The results of this investigation showed the need for incessant new research on COVID-19, mainly due to the current pandemic critical moment, especially on the theme tangent to this disease in the renal system in the short, medium and long term, in order to contemplate best practices for patients. However, despite the topic specificity, this is one of the rare and most complete reviews on the subject today, providing valuable insights for understanding $\mathrm{AKI}$ and kidney dysfunction in patients with COVID-19. The pathogenic aspects and clinical manifestations referring to hospitalized patients in serious condition and to those who died due to the latest published scientific evidence were mainly presented. Using the information in this review will help nurses and other health professionals to pay attention to identify potential renal risks to those affected with COVID-19, recognize clinical priorities and potential and support safe care.

The data in this review may corroborate future monitoring of renal functions of these patients in potential later protocols, which can effectively improve success rate of treatment for COVID-19, especially in patients at high risk of death, contributing to the incessant fight against this terrible disease. AKI and renal dysfunction cannot be ignored in COVID-19 clinical care and practice.

\section{CONCLUSION}

The studies presented relevant levels of evidence, with an experimental approach to the mechanism of intracellular infection of SARS-CoV-2. Viral cytopathic effect on renal cells stood out, suggesting $A K I$ and damage to the kidney and renal function. Observational studies, with data on the incidence of AKI in patients admitted due to COVID-19, were found to be inconsistent, ranging from $0 \%$ to $29 \%$. However, it appears that the occurrence of AKI, together with the analysis of other renal parameters, proves to be an important clinical complication and is associated with increased mortality and morbidity in these patients.

Therefore, this review realizes the need to formulate new research that may mention kidney care to patients with COVID-19.

\section{FUNDING}

Conselho Nacional de Desenvolvimento Científico e Tecnológico - CNPq.

\section{REFERENCES}

1. Lana R M, Coelho FC, Gomes MFC, Cruz OG, Bastos LS, Villela DAM, et al. Emergência do novo coronavírus (SARS-CoV-2) e o papel de uma vigilância nacional em saúde oportuna e efetiva. Cad Saúde Pública. 2020;36(3):e00019620. doi: 10.1590/0102-311x00019620 
2. $\mathrm{Xu} \mathrm{J}$, Zhao S, Teng T, Abdalla AE, Zhu W, Xie L, et al. Systematic comparison of two animal-to-human transmitted human coronaviruses: SARS-CoV-2 and SARS-CoV. Viruses. 2020;12(2):244. doi: 10.3390/v12020244

3. Sun P, Lu X, Xu C, Sun W, Pan B. Understanding of COVID-19 based on current evidence. J Med Virol. 2020;92:548-51. doi: 10.1002/jmv.25722

4. Fan Y, Zhao K, Shi Z-L, Zhou P. Bat Coronaviruses in China. Viruses [Internet]. 2019 [cited 2020 Apr 11];11(3):210. Available from: https://www. ncbi.nlm.nih.gov/pmc/articles/PMC6466186/

5. Cheng VCC, Lau SKP, Woo PCY, Yuen KY. Severe Acute Respiratory Syndrome Coronavirus as an agent of emerging and reemerging infection. Clin Microbiol Rev [Internet]. 2007 [cited 2020 Apr 11];20(4):660-94. Available From: https://www.ncbi.nlm.nih.gov/pmc/articles/ PMC2176051/

6. Bastos L. OPAS/OMS Brasil - Folha Informativa - COVID-19 (Doença Causada Pelo Novo Coronavírus) | OPAS/OMS. [Internet]. 2020. Pan American Health Organization/World Health Organization. [cited 2020 Apr 11]. Available from: https://www.paho.org/bra/index. php?option=com_content\&view=article\&id=6101: covid19\&ltemid $=875$

7. Cascella M, Rajnik M, Cuomo A, Dulebohn SC, Di Napoli R. Features, Evaluation and Treatment Coronavirus (COVID-19). In: StatPearls [Internet]. Treasure Island (FL): StatPearls Publishing; 2020 [cited 2020 Apr 11]. Available From: http://www.ncbi.nlm.nih.gov/books/NBK554776/

8. Huang C, Wang Y, Li X, Ren L, Zhao J, Hu Y, et al. Clinical features of patients infected with 2019 novel coronavirus in Wuhan, China. Lancet [Internet]. 2020 [cited 2020 Apr 11];395(10223):497-506. Available from: https://www.thelancet.com/journals/lancet/article/ PIIS0140-6736(20)30183-5/abstract

9. Wang D, Hu B, Hu C, Zhu F, Liu X, Zhang J, et al. Clinical characteristics of 138 hospitalized patients with 2019 novel coronavirus-infected pneumonia in Wuhan, China. JAMA [Internet]. 2020 [cited 2020 Apr 11];323(11):1061-9. Available from: https://jamanetwork.com/journals/ jama/fullarticle/2761044

10. Peeri NC, Shrestha N, Rahman MS, Zaki R, Tan Z, Bibi S, Baghbanzadeh M, Aghamohammadi N, Zhang W7, Haque U. The SARS, MERS and novel coronavirus (COVID-19) epidemics, the newest and biggest global health threats: what lessons have we learned? Int J Epidemiology [internet]. 2020 [cited 2020 Apr 11];dyaa033. Available from: https://doi.org/10.1093/ije/dyaa033

11. Zhang W, Zhao Y, Zhang F, Wang Q, Li T, Liu Z, et al. The use of anti-inflammatory drugs in the treatment of people with severe coronavirus disease 2019 (COVID-19): the experience of clinical immunologists from China. Clin Immunol Orlando Fla [Internet]. 2020 [cited 2020 Apr 11];214: 10839. Available from: https://www.ncbi.nlm.nih.gov/pmc/articles/PMC7102614/

12. Hui DSC, Zumla A. Severe acute respiratory syndrome: historical, epidemiologic, and clinical features. J Infect Dis Clin North Am [Internet]. 2019 [cited 2020 Apr 11];33(4):869-89. Available from: https://www.sciencedirect.com/science/article/pii/S0891552019300571?via\%3Dihub

13. Janka GE, Lehmberg K. Hemophagocytic syndromes: an update. Blood Rev [Internet]. 2014 [cited 2020 Apr 11];28(4):135-42. Available From: http://www.sciencedirect.com/science/article/pii/S0268960X14000289

14. Mehta P, McAuley DF, Brown M, Sanchez E, Tattersall RS, Manson JJ. COVID-19: consider cytokine storm syndromes and immunosuppression. Lancet [Internet]. 2020 [cited 2020 Apr 11];395(10229):1033-4. Available From: https://www.thelancet.com/journals/lancet/article/ PIIS0140-6736(20)30628-0/abstract

15. Zhou F, Yu T, Du R, Fan G, Liu Y, Liu Z, et al. Clinical course and risk factors for mortality of adult inpatients with COVID-19 in Wuhan, China: a retrospective cohort study. Lancet [Internet]. 2020 [cited 2020 Apr 11];395(10229):1054-62. Available From: https://www.thelancet.com/ journals/lancet/article/PIIS0140-6736(20)30566-3/abstract

16. Bernardes J. Covid-19 tem possível associação com inflamação renal, apontam estudos. J USP [Internet]. 2020 [cited 2020 Apr 11]. Available From: https://jornal.usp.br/ciencias/ciencias-da-saude/covid-19-tem-possivel-associacao-com-inflamacao-renal-apontam-estudos/

17. Strabelli TMV, Uip DE. COVID-19 and the Heart. Arq Bras Cardiol [Internet]. 2020 [cited 2020 Apr 11]. doi: 10.36660/abc.20200209

18. Li Z, Wu M, Yao J, Guo J, Liao X, Song S, et al. Caution on Kidney Dysfunctions of COVID-19 Patients. medRxiv [Internet]. 2020 [cited 2020 Apr 12];2020.02.08.20021212. Available From: https://www.medrxiv.org/content/10.1101/2020.02.08.20021212v2

19. Cheng Y, Luo R, Wang K, Zhang M, Wang Z, Dong L, Li J, Yao Y, Ge S, Xu G. Kidney disease is associated with in-hospital death of patients with COVID-19. Kidney Int [Internet]. 2020 [Cited 2020 Apr 12];97(5);829-838. Available From: https://www.kidney-international.org/article/ S0085-2538(20)30255-6/fulltext

20. Xu D, Zhang H, Gong H, Chen J, Ye J, Meng T, et al. Identification of a potential mechanism of acute kidney injury during the Covid-19 outbreak: a study based on single-cell transcriptome analysis. Intensive Care Med [internet]. 2020 [cited 2020 Apr 12]. Available From: https://link.springer.com/article/10.1007/s00134-020-06026-1\#citeas

21. Wang L, Li X, Chen H, Yan S, Li D, Li Y, et al. Coronavirus Disease 19 infection does not result in acute kidney injury: an analysis of 116 hospitalized patients from Wuhan, China. Am J Nephrol [Internet]. 2020 [cited 2020 Apr 12];1-6. Available From: https://www.karger.com/ Article/FullText/507471

22. Beyea SC, Nicoll LH. Writing an integrative review. AORN J [Internet]. 1998 [cited 2020 Apr 12];67(4):877-80. Available From: https:// aornjournal.onlinelibrary.wiley.com/doi/abs/10.1016/S0001-2092\%2806\%2962653-7

23. Whittemore R, Knafl K. The integrative review: updated methodology. J Adv Nurs [Internet]. 2005 [cited 2020 Apr 13];52(5):546-53. Available from: http://users.phhp.ufl.edu/rbauer/EBPP/whittemore_knafl_05.pdf

24. Santos CMC, Pimenta CAM, Nobre MRC. A estratégia PICO para a construção da pergunta de pesquisa e busca de evidências. Rev Latino-Am Enfermagem [Internet]. 2007 [cited 2020 Apr 13];15(3):508-11. doi: 10.1590/S0104-11692007000300023 
25. Melnyk B, Fineout-Overholt E. Evidence based practice in nursing \& healthcare: a guide to best practice. Philadelphia: Lippincot Williams \& Wilkins 2005. 3-24p.

26. Chen T, Wu D, Chen H, Yan W, Yang D, Chen G, et al. Clinical characteristics of 113 deceased patients with coronavirus disease 2019: retrospective study. BMJ [Internet]. 2020 [cited 2020 Apr 12];368m1091. Available From: https://www.bmj.com/content/368/bmj.m1091

27. Deng Y, Liu W, Liu K, Fang Y-Y, Shang J, Zhou L, et al. Clinical characteristics of fatal and recovered cases of coronavirus disease 2019 (COVID-19) in Wuhan, China: a retrospective study. Chin Med J (Engl). 2020;133(11):1261-7 doi: 10.1097/CM9.0000000000000824

28. Yang X, Yu Y, Xu J, Shu H, Xia J, Liu H, et al. Clinical course and outcomes of critically ill patients with SARS-CoV-2 pneumonia in Wuhan, China: a single-centered, retrospective, observational study. Lancet Respir Med[Internet] 2020[cited 2020 Apr 12];S2213-2600(20)30079-5. Available From: https://www.thelancet.com/journals/lanres/article/PIIS2213-2600(20)30079-5/fulltext

29. Fan C, Li K, Ding Y, Lu WL, Wang J. ACE2 Expression in Kidney and Testis May Cause Kidney and Testis Damage After 2019-nCoV Infection. medRxiv [Internet]. 2020 [cited 2020 Apr 12]. Available From: http://medrxiv.org/content/early/2020/02/13/2020.02.12.20022418.abstract

30. Zhang H, Penninger JM, Li Y, Zhong N, Slutsky AS. Angiotensin-converting enzyme 2 (ACE2) as a SARS-CoV-2 receptor: molecular mechanisms and potential therapeutic target. Intensive Care Med [Internet]. 2020 [cited 2020 Apr 12];46(4);586-90. Available from: https:// link.springer.com/article/10.1007\%2Fs00134-020-05985-9.

31. Zhao Y, Zhao Z, Wang Y, Zhou Y, Ma Y, Zuo W. Single-cell RNA expression profiling of ACE2, the receptor of SARS-CoV-2. bioRxiv [Internet]. 2020[cited 2020 Apr 12];2020.01.26.919985. Available from: http://biorxiv.org/content/early/2020/04/09/2020.01.26.919985.abstract

32. World Health Organization - WHO. Coronavirus [Internet]. 2020[cited 2020 Apr 14]. Available from: https://www.who.int/emergencies/ diseases/novel-coronavirus-2019

33. Ministério da Saúde (BR). Coronavírus: saiba o que é, como tratar, se prevenir e últimas notícias [Internet]. 2020[cited 14 de abril de 2020]. Available From: https://www.saude.gov.br/o-ministro/746-saude-de-a-a-z/46490-novo-coronavirus-o-que-e-causas-sintomas-tratamentoe-prevencao-3

34. Khwaja A. KDIGO Clinical Practice Guidelines for Acute Kidney Injury. Nephron Clin Pract [Internet]. 2012 [cited 2020 Apr 14];120(4):c179-84. Available From: https://www.karger.com/Article/FullText/339789

35. Xu Z, Shi L, Wang Y, Zhang J, Huang L, Zhang C, et al. Pathological findings of COVID-19 associated with acute respiratory distress syndrome. Lancet Respir Med [Internet]. 2020 [cited 2020 Apr 14];8(4):420-2. Available From: https://www.thelancet.com/journals/lanres/article/ PIIS2213-2600(20)30076-X/abstract

36. Jefferson J, Nelson P, Najafian B, Shankland S, Podocyte Disorders: Core Curriculum 2011. Am J Kidney Dis[Internet]. 2011 [cited 2020 Apr 14];58(4):666-77. Available From: https://www.ajkd.org/article/S0272-6386(11)01071-7/fulltext

37. Chai X, Hu L, Zhang Y, Han W, Lu Z, Ke A, et al. Specific ACE2 Expression in Cholangiocytes may cause liver damage after 2019nCoV infection. bioRxiv [Internet]. 2020 [cited 2020 Apr 14];2020.02.03.931766. Available From: http://biorxiv.org/content/ early/2020/02/04/2020.02.03.931766.abstract

38. Chan JF-W, Yuan S, Kok K-H, To KK-W, Chu H, Yang J, et al. A familial cluster of pneumonia associated with the 2019 novel coronavirus indicating person-to-person transmission: a study of a family cluster. Lancet [Internet]. 2020 [cited 2020 Apr 14];395(10223):514-23. Available From: https://www.thelancet.com/journals/lancet/article/PIIS0140-6736(20)30154-9/abstract

39. He L, Ding Y, Zhang Q, Che X, He Y, Shen H, et al. Expression of elevated levels of pro-inflammatory cytokines in SARS-CoV-infected ACE2+ cells in SARS patients: relation to the acute lung injury and pathogenesis of SARS. J Pathol [Internet]. 2006[cited 2020 Apr 14];210(3):288-97. Available From: https://onlinelibrary.wiley.com/doi/full/10.1002/path.2067

40. Ruan Q, Yang K, Wang W, Jiang L, Song J. Clinical predictors of mortality due to COVID-19 based on an analysis of data of 150 patients from Wuhan, China. Intensive Care Med. 2020;46:846-8. Available From: 10.1007/s00134-020-06028-z

41. Chen N, Zhou M, Dong X, Qu J, Gong F, Han Y, et al. Epidemiological and clinical characteristics of 99 cases of 2019 novel coronavirus pneumonia in Wuhan, China: a descriptive study. The Lancet [Internet]. 2020 [cited 2020 Apr 14];395(10223):507-13. Available From: https:// www.thelancet.com/journals/lancet/article/PIIS0140-6736(20)30211-7/abstract

42. Wu C, Chen X, Cai Y, Xia J, Zhou X, Xu S, et al. Risk factors associated with acute respiratory distress syndrome and death in patients with Coronavirus Disease 2019 Pneumonia in Wuhan, China. JAMA Intern Medicine[Internet]. 2020 [cited 2020 Apr 14]. Available From: https:// jamanetwork.com/journals/jamainternalmedicine/fullarticle/2763184

43. Sheng W-H, Chiang B-L, Chang S-C, Ho H-N, Wang J-T, Chen Y-C, et al. Clinical manifestations and inflammatory cytokine responses in patients with severe acute respiratory syndrome. J Formos Med Assoc [Internet]. 2005 [cited 2020 Apr 14];104(10):715-23. Available from: https://pubmed.ncbi.nlm.nih.gov/16385373/

44. Ward SE, Loutfy MR, Blatt LM, Siminovitch KA, Chen J, Hinek A, et al. Dynamic changes in clinical features and cytokine/chemokine responses in SARS patients treated with interferon alfacon-1 plus corticosteroids. Antivir Ther [Internet]. 2005 [cited 2020 Apr 14];10(2):26375. Available from: https://pubmed.ncbi.nlm.nih.gov/15865221/

45. Bellomo R, Kellum JA, Ronco C, Wald R, Martensson J, Maiden M, et al. Acute kidney injury in sepsis. Intensive Care Med. 2017;43(6):816-28. doi: 10.1007/s00134-017-4755-7

46. Rather A, Kasana B. The Third International Consensus Definitions for Sepsis and Septic Shock (Sepsis-3). JMS SKIMS [Internet]. 2015 [cited 2020 Apr 14];18(2):162-4. Available From: https://jamanetwork.com/journals/jama/fullarticle/2492881 